\title{
山岳トンネル施工支援のための切羽 評価法の適用性に関する研究
}

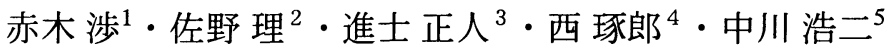 \\ 1正会員 日本道路公団試験研究所 道路研究部トンネル研究室（テ194-8508 東京都町田市忠生1-4-1） \\ 2正会員 工修 応用地質株式会社 長野支店（广380-0912 長野県長野市大字稲葉字日詰冲1593-1） \\ 3正会員 学博 応用地質株式会社 技術本部（T330-8632 埼玉県大宮市土呂町2-61-5） \\ 4正会員 理博 清水建設株式会社 和泉研究室（广100-0011 東京都千代田区内幸町2-2-2） \\ 5正会員 工博 山口大学工学部社会建設工学科教授（干755-8611 山口県宇部市常盤台2-16-1）
}

\begin{abstract}
NATMは，計測と施工が一体化したトンネル渭削工法であり，その導入からすでに 20 年が経過してい る.この間に蓄積された計測データを有効に活用することにより，合理的な山岳トンネル施工を目指すこ とは今後極めて重要となる. 日本道路公団では, 従来の地質的な記載が中心で, 地山状態を定性的に評価 する切羽観察手法を改め, 切羽状態をより定量的に評価できる切羽評価法を提案した. そこで, 本論文で は, この評価法により収集された 6,101 断面の切羽観察結果データベースを活用し, 切羽観察項目の寄与 度を数量化する. そして, 湧水や劣化による評価点の調整方法について議論し, この切羽評価法を実際の トンネル施工事例に適用した際，妥当な評価結果が得られたことを記述する.
\end{abstract}

Key Words : tunnel face, geological observations, rock mass classifications, support determination methods

\section{1.はじめに}

山岳トンネルの標準施工法としてNATMが位置付け られてほぼ 20 年が経過した. NATMは, 現場計測を 一つの判断基準として活用する施工法と位置付けら れており,この間に蓄積された計測デー夕は膨大で ある. 今後の山岳トンネルの施工においては, 蓄積 された計測デー夕を可能な限り有効利用することに より, 施工時の安全性を確保することはもちろん, より合理的かつ経済的な山岳トンネル施工への取り 組みがこれまで以上に期待されている.

1997年から日本道路公団（以下JHと呼ぶ）では, NATMの標準支保パターンとして自らが設定したB〜 DIパターンの施工実績に基づき, 画一的な支保パタ ーンの選択から，地質状況により見合った柔軟な支 保パターンの選択ができるように標準支保パターン の追加・修正を行ういわゆる「支保パターンのマル チ化」に取り組んできた.これら標準支保パターン を弾力的に適用する（マルチ化する）ためには, 事 前調查段階で設定した支保パターンを施工時の現場 計測, 切羽観察に基づいて修正していく必要がある. NATM導入時から, JHでは切羽観察の重要性を認識し, 独自に切羽観察様式を制定し, 切羽観察デー夕を収
集している．そのデータに基づき，施工者を含めた 岩判定委員会を組織してその委員会の中でこれまで の計測データおよび切羽観察結果を評価し, 今後の 支保パターンの検討を行い, 必要に応じて支保パタ 一ンの変更を実施している. すなわち, 切羽観察結 果は, 地山状態を評価する重要な情報すなわち岩盤 評価として, 支保判定材料の一つとして用いられて いる. しかし, JHの従来の切羽観察手法は, 何人か の研究者により切羽観察結果の定量的な評価が試み られているものの, 観察結果と支保パターンとの関 連性が明確に数值化されていなかった. 従来の岩盤 評価としては, 地山分類あるいは岩盤分類としてト ンネル, ダムなどのそれぞれの構造物に特化した数 多くの提案がなされている. 山岳トンネルでは, Bartonが提案したQ-system ${ }^{1)}$, Bieniawskiによる $\mathrm{RMR}^{2)}$ が世界的によく用いられている. しかし,これ らの方法は, 地山が比較的均質かつ硬質で良好な状 態における岩盤評価を目的に考案されたものであり， そのままわが国に導入できるとは考えにくい. わが 国においても, トンネルの岩盤評価の取り組みは数 多くなされているが，それらの多くは特定のトンネ ルあるいは限られた地域を対象としたものである. そこで, 筆者らは, 切羽観察デー夕を数量化類に 
表-1 従来の切羽観察様式

\begin{tabular}{|c|c|c|c|c|c|c|}
\hline \multicolumn{2}{|c|}{ 土 被 } & \multirow{2}{*}{\multicolumn{2}{|c|}{\begin{tabular}{c|r}
$\mathrm{m}$ & 棇合判断 \\
\end{tabular}}} & \multicolumn{3}{|c|}{ 地山区分あるいはパターン区分の判定 } \\
\hline \multicolumn{2}{|c|}{ 岩 } & & & \multicolumn{3}{|c|}{\begin{tabular}{|c|r|r} 
岩 $\begin{array}{r}\text { 名 } \\
\text { 形成地貫時代 }\end{array}$ & \\
\end{tabular}} \\
\hline & $\begin{array}{r}\text { 殊 条 件 } \\
\text { 態 }\end{array}$ & \multicolumn{5}{|c|}{ 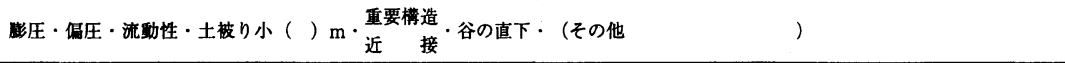 } \\
\hline \multicolumn{7}{|c|}{ 掘削地点の地山の状態と挙動 } \\
\hline (4) & 切羽の状態 & 1. 安 & $\begin{array}{l}\text { 2. 鏡面から岩塊が抜け } \\
\text { 落ちる }\end{array}$ & $\begin{array}{l}\text { 3. 鏡面の押し出しを生 } \\
\text { じる }\end{array}$ & $\begin{array}{l}\text { 4. 鏡面は自立せず崩れ } \\
\text { あるいは流出 }\end{array}$ & 5. その他 \\
\hline (B) & 素掘面の状龍 & $\begin{array}{l}\text { 1. 自 立 } \\
\text { (普請不要) }\end{array}$ & $\begin{array}{l}\text { 2. 時間がたつとゆるみ } \\
\text { 肌落ちする（後普請） }\end{array}$ & $\begin{array}{c}\text { 3. 自立困雜掘削後早期 } \\
\text { に支保する（先普請） }\end{array}$ & $\begin{array}{r}\text { 4. 掘削に先行して山を } \\
\text { 受けて扔く必要がある }\end{array}$ & 5 . \\
\hline (C) & 圧 縮 強 度 & $\begin{aligned} & \text { 1. } \sigma_{\mathrm{c}} \geq 1000 \mathrm{kgf} / \mathrm{cm}^{2} \\
& \text { ハンマー打慗はね返る }\end{aligned}$ & $\begin{array}{l}\text { 2. } 1000>\sigma_{\mathrm{c}} \geq 200 \\
\text { ハンマー打繁でくだける }\end{array}$ & $\begin{aligned} & \text { 3. } 200>\sigma_{\mathrm{c}} \geq 50 \\
& \text { 軽い打慗でくだける }\end{aligned}$ & $\begin{array}{l}\text { 4. } 50 \mathrm{kgf} / \mathrm{cm}^{2}>\sigma_{\mathrm{c}} \\
\text { ハンマー刃先喰いこむ }\end{array}$ & 5 . \\
\hline (1) & 風 化 変 筫 & 1. なし · 揵全 & $\begin{array}{l}\text { 2. 岩目に沿って変色強度 } \\
\text { やや低下 }\end{array}$ & $\begin{array}{l}\text { 3. 全体に変色, 強度相 } \\
\text { 当に低下 }\end{array}$ & $\begin{array}{c}\text { 4. 土砂状, 粘土状, 破 } \\
\text { 研, 当初より未固結 }\end{array}$ & 5 . \\
\hline (B) & 割れ目の精度 & $\begin{array}{l}\text { 1. 間陆 } \mathrm{d} \geq 1 \mathrm{~m} \\
\text { 割れ目なし }\end{array}$ & 2. $1 \mathrm{~m}>\mathrm{d} \geqq 20 \mathrm{~cm}$ & 3. $20 \mathrm{~cm}>\mathrm{d} \geqq 5 \mathrm{~cm}$ & $\begin{array}{l}\text { 4. } 5 \mathrm{~cm}>\mathrm{d} \text { 破研, 当初 } \\
\text { より末固䊅 }\end{array}$ & 5 . \\
\hline (F) & 割れ目の状態 & 1. 密 & 2. 部分的に開口 & 3. 開 & $\begin{array}{l}\text { 4. 粘土をはさむ, 当初 } \\
\text { より末固結 }\end{array}$ & 5 . \\
\hline (G) & 割れ目の形態 & $\begin{array}{c}\text { 1.・ンタム } \\
\text { 方 形 }\end{array}$ & 2. 柱 状 HHH & $\begin{array}{l}\text { 3. 層状, 片状 } \\
\text { 板状 }\end{array}$ & $\begin{array}{l}\text { 4. 土砂状, 細片状, 当 } \\
\text { 初上り末固結 }\end{array}$ & 5 . \\
\hline (1) & 湧 & 1. なし, 水程度 & 2. 道水程度 & 3. 集中溥水 & 4. 全面涌水 & 5 . \\
\hline (1) & 水による劣化 & 1. な & 2. ゆるみを生ず & 3. 軟 弱 化 & 4. 崩壤 - 流出 & 5 . \\
\hline \multirow{2}{*}{ 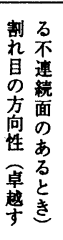 } & $\begin{array}{c}\text { 㮆 断 } \\
\text { 方 向 } \\
\text { (切羽面をみて) }\end{array}$ & \multicolumn{5}{|c|}{ 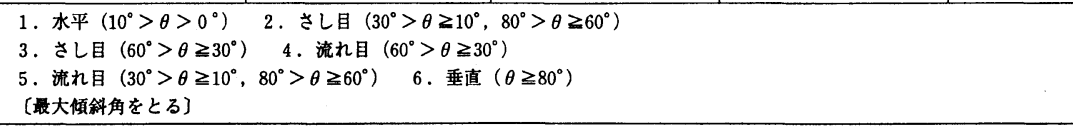 } \\
\hline & $\begin{array}{c}\text { 横 } \quad \text { 断 } \\
\text { 方 向 } \\
\text { (切羽面をみて) }\end{array}$ & \multicolumn{5}{|c|}{$\begin{array}{l}\text { 1. 水平 }\left(10^{\circ}>\theta \geqq 0^{\circ}\right) \quad \text { 2. 右から左へ }\left(30^{\circ}>\theta \geq 10^{\circ}, 80^{\circ}>\theta \geqq 60^{\circ}\right) \\
\text { 3. 右から左へ }\left(60^{\circ}>\theta \geq 30^{\circ}\right) \quad 4 \text {. 左から右へ }\left(60^{\circ}>\theta \geqq 30^{\circ}\right) \\
\text { 5. 左から右人 }\left(30^{\circ}>\theta \geqq 10^{\circ}, 80^{\circ}>\theta \geqq 60^{\circ}\right) \quad \text { 6. 垂直 }\left(\theta \geqq 80^{\circ}\right) \\
\text { (切羽面のみかけの傾斜角をとる] }\end{array}$} \\
\hline
\end{tabular}

より観察項目の類似性分析と類似性からみた岩種の 分類を行い, 観察項目の整理を行った. そして, 新 しい切羽評価法の枠組みを提案し, 現行の切羽観察 と新しい切羽観察を用いた評価点法（以下，「新評 価点法」と呼ぶ）による支保パターンの判別に関す る比較を実施した ${ }^{3)}$.

新評価点法は，1996年11月からJHに試行導入され ている.この手法による施工データも蓄積され, 現 時点では分析を行うのに十分なデー夕数に達してい る. そこで本論文ではより合理的な山岳トンネル施 工を支援するために切羽評価結果を数量化すること を目的として，各観察項目の支保パターンに対する 寄与度を重みとして評価した．そして，その結果を 実際の施工事例に適用しその適用性について検証し た.

\section{2. 切羽評価法}

\section{（1）従来の切羽評価法の問題点}

トンネル周辺の地山挙動を支配する地質的な因子 を整理して，切羽の安定性を評価する手法には，
種々の方法が提案されている，JHがNATM導入時に制 定した切羽観察の様式を表一 1 に示す ${ }^{3)}$. 当初の切 羽観察手法の考え方は，この様式に見られるように 切羽の状況を定性的に記載することにより，これら の観察項目と変位量等の計測結果からトンネル技術 者の総合的な判断を支援する記録資料としての性格 を有するものとされてきた．従って，それぞれの項 目の記載にも定性的な記述が多いことがその特徵の ひとつである.

この表を使って, 切羽観察結果から支保パターン を定量的に評価する試みは多くの研究者により何度 か行われてきた ${ }^{4), 5)}$ ，筆者らは従来の切羽観察様式 を改良し，地山評価，支保判定のための資料とする ため, 特に観察項目の選択に関しては, クラスター 分析を行い, その結果, 切羽評価を「総合的な岩盤 強度に対する評価」と「場の状態に対する評価」を 組み合わせて実施するものと定義した．すなわち， 新評価点法における岩盤強度に関する項目は, 「圧縮 強度」,「風化変質」,「割れ目の間隔」,「割れ目の状 態」の 4 項目, 場の状態に対する評価区分は, 「湧水 量」,「（水による）劣化」,「地山強度比」とした. これまでの検討 ${ }^{3)}$ と同様, 土被りが概ね $1000 \mathrm{~m}$ 以下の 
表 - 2 新しい切羽観察様式

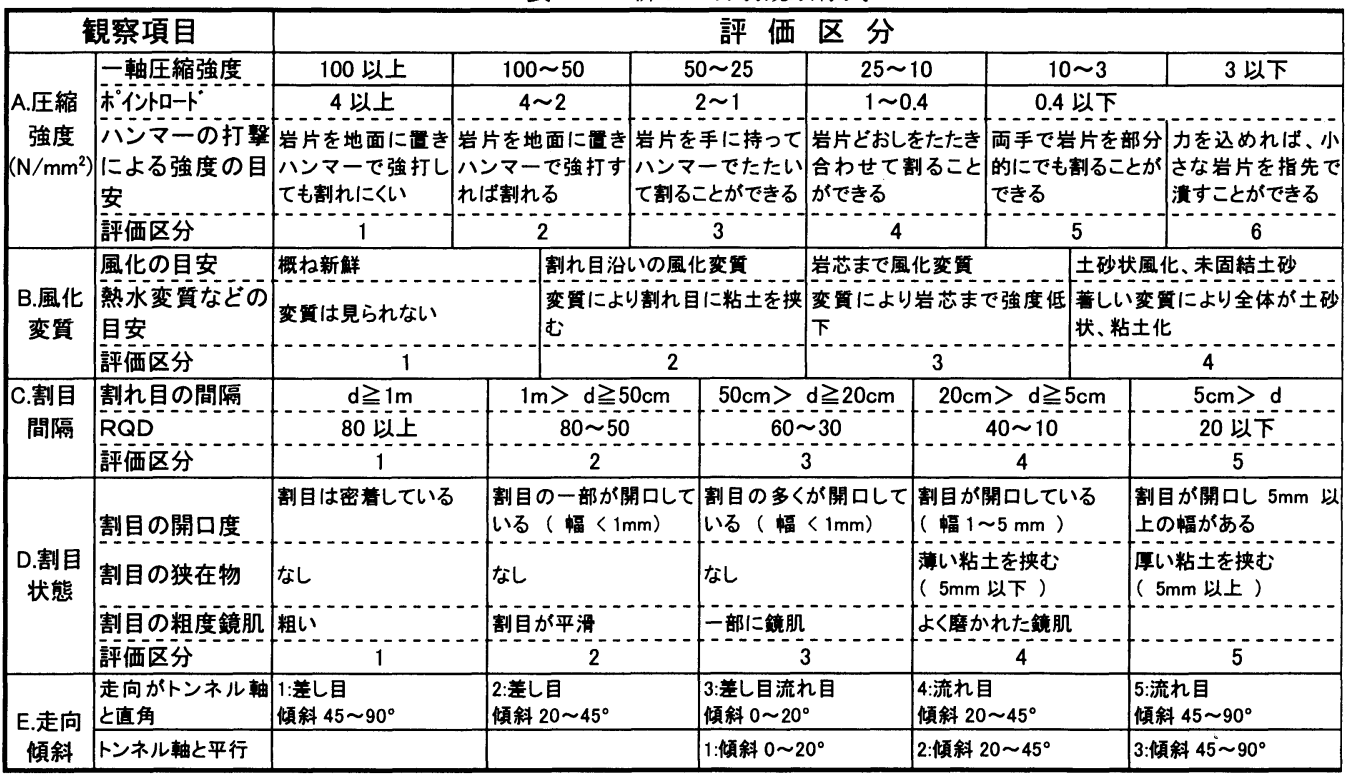

切羽 $10 \mathrm{~m}$ 区間での湧水量と水による劣化状態による評価(劣化は現在および将来における可能性について判定する)

\begin{tabular}{|c|c|c|c|c|c|}
\hline F.湧水 & 桨態 & 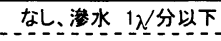 & 滴水程度 1 1 20ㅈㅅㄱ & 集中湧水 20 100ㅅ 分 & 全面湧水 $100 \mathrm{~N}$ 分以上 \\
\hline 量 & 評価区分 & 1 & 2 & 3 & 4 \\
\hline G 劣化 & 水による劣化 & なし & 緩みを生ず & 慗弱化 & 流出 \\
\hline G.劣化 & 評価区分 & 1 & 2 & 3 & 4 \\
\hline
\end{tabular}

通常のトンネルでは、地山強度比が地山状態の指標 となりうる岩石は限定されているようであり, 試行 導入後の地山強度比と変位量とのデー夕検討では, 支保パターン並びに地山状態, 変位量などの明確な 関係が得られなかった. 従って, 観察項目から除外 し，切羽観察シートには土被り高を記入する欄を設 け，今後に向けてデータとして蓄積することとした．

同様に, RMRなどで採用されている「不連続面 の走向・傾斜」とトンネルの位置関係は、場の状態 を表す観察項目として, 切羽状況の判断に影響を与 えるものと考えられる. しかし、現状ではデー夕量 が不十分なため、今回新たに観察項目に加え, デー タ収集を行うこととした。

従って,「圧縮強度」,「風化変質」,「割れ目の間 隔」,「割れ目の状態」という総合的な岩盤強度に関 する 4 項目の観察項目の足し合わせで最高点の 10 0 点を構成し, その点数に対して, 「湧水量」,

「劣化」,「不連続面の走向・傾斜」という場の状 態に対する 3 項目の調整点を減じる考え方とした.

表一 2 に新評価点法で使用する切羽観察データシー トを示す. 実際の切羽観察では, 切羽スケッチとと もにこのデータシートを記入し切羽の評価を行うこ とになっている.

表ー 1 と表ー 2 を比較すると明らかなように, 新
表-3 岩石グループの区分

\begin{tabular}{|c|c|c|c|}
\hline$\underbrace{\text { 強度区分 }}_{\text {風化区分 }}$ & 硬質岩 & 中硬質岩 & 軟質岩 \\
\hline \multirow[b]{2}{*}{ 塊 状 } & $\begin{array}{l}\text { グループ } 1 \\
\text { [硬犋岩・塊状] }\end{array}$ & \multicolumn{2}{|c|}{$\begin{array}{l}\text { グループ } 2 \\
\text { [中硬孟岩・塊状、軟質岩・塊状] }\end{array}$} \\
\hline & $\begin{array}{l}\text { 花崗岩、中古生 } \\
\text { 層砂岩、石英斑 } \\
\text { 岩、花崗閃緑岩 } \\
\text { など }\end{array}$ & \multicolumn{2}{|c|}{$\begin{array}{l}\text { 疑灰岩、火山皪疑灰岩、流紋岩、 } \\
\text { 安山岩、玄武岩、砂岩など }\end{array}$} \\
\hline \multirow{3}{*}{ 層 状 } & & \multirow{2}{*}{$\begin{array}{l}\text { グループ } 3 \\
\text { [中硬幽岩・層 } \\
\text { 状] }\end{array}$} & 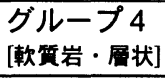 \\
\hline & & & 纽角峛 \\
\hline & & $\begin{array}{l}\text { 中古生層頁岩、 } \\
\text { 粘板岩など }\end{array}$ & $\begin{array}{l}\text { 片岩、第三紀層 } \\
\text { 泥岩など }\end{array}$ \\
\hline
\end{tabular}

評価点法は, 定量的に評価の可能な観察項目は評価 区分の分割数を增やしている，例えば，「圧縮強 度」に関係する観察項目に関しては 6 分割,「割れ 目の間隔」,「割れ目の状態」に関しては 5 分割し, それらの評価区分の感度をより高めるようにしてい る. 


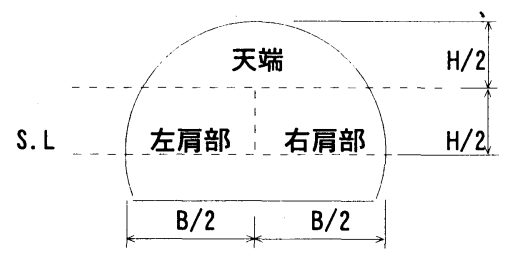

図一 1 切羽分割概念図

\section{(2) 岩石のグループ分け}

各観察項目の評価区分の寄与度が岩種により異な ることは，十分予想される，八木らは，これまでの JHに蓄積された現場計測データを分析し, 支保パ夕 ーンと内空変位の発生量を岩種毎に整理した結果, 同じ変形挙動を示すいくつかの岩石グループに分類 できることを述べている ${ }^{6)}$ ．また，今田は地山特性 とトンネル挙動を整理する際, 地山強度と不連続性 の大小で緩み荷重が変化することを示唆している7) そこで，ここでは八木らの区分を参考として，表3 に示すように一般的な岩石グループを各岩石の新 鮮な状態での圧縮強度とその後の風化・劣化形態に より 4 区分し，それぞれの区分に対して観察項目の 奇与度を検討することにした，以下，簡便のため, 各岩石グループを表中に示す岩石グループ名 ${ }^{3)}$ で呼 ぶこととする.

\section{（3）切羽の分割に関する評価}

新評価点法を試行導入する際に, ひとつの切羽に 複数の岩種が出現する場合や風化・劣化の程度が切 羽内で異なる場合が考えられる.このような場合, 切羽をどのように評価するかが問題となる. 鈴木 $ら^{8)}$ の研究では, トンネル技術者は, 切羽安定の評 価として, 切羽天端付近における不連続面の状態を 重視していることを示唆している. そこで, 切羽の 評価を図ー 1 に示すようにトンネル高さで 2 等分し, その上部を天端部とした. そして, 下部をトンネル 中心線で左右局部として分割し，それぞれ 3 分割さ れた切羽を独立に評価することとした．3分割され たそれぞれの切羽評価区分值について, それらの平 均值, 最小值, 加重平均值などの值と支保パターン との関係をいくつかのトンネルでトンネル縦断方向 に整理したが, 有意差は認められなかった. しかし，

(1) 切羽観察者から，地山全体の評価に関しては、 天端部の評価比重を大きくした方がよいとい う意見が多数寄せられたこと.

(2) 2 車線道路トンネルでは, それぞれの分割さ れた切羽の面積が, 天端部面積 : 各肩部面積 $\fallingdotseq 1.28: 1$ となること.

等を考慮して, 切羽の安定に大きな影響を与える天 端部の評価結果を左右両肩部の結果より重く（切羽 を代表する評価点としては天端を 2 倍）評価する加 重平均法を用いることにした. すなわち, 評価区分 值の加重平均値は, 天端部の地山状況が比較的良好 な場合は, 切羽全体をより良好と判断するように切 羽断面を 3 分割して評価した時の(左肩部+天端部 $\times 2$ +右肩部 $) \div 4$ で算出したもので, この場合, 切羽の評価区分值は 0.25 刻みになる. また, 個々の 観察項目において, 切羽全体を代表させる場合には この重みがついた区分値を使用することとした.

\section{3. 各評価区分の評価配点の考え方}

\section{（1）基本的考え方}

トンネルの支保構造は, 施工時の安全性を担保し た上で, 所定の内空断面を確保することが必要条件 である．従って，地山と支保の両者の剛性をうまく 組み合わせ, 各支保パターンにおいて発生する変位 が各支保パターンにおける許容変形量以下に収まる ように過不足なく施工することが理想である.すな わち, 施工後, 過不足ない変形が生じた切羽観察結 果は, 支保選定の判断基準としての適切な地山の支 保剛性を評価していると判断してよい.

新評価点法では，「圧縮強度」，「風化変質」，

「割れ目の間隔」，「割れ目の状態」という総合的 な岩盤強度に関する 4 項目の観察項目を用いて地山 状態を表現している．それぞれの観察項目の独立性

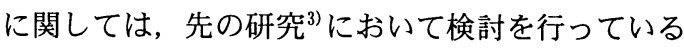
ので, 総合評価としてはそれぞれの岩石グループ毎 に観察項目の寄与度の検討を行う.

支保パターンと観察項目との関係を整理するため には，支保剛性に関する定量化を行う必要がある. しかし, 支保剛性の評価に関しては, 経験的な手法 から理論的な手法まで種々提案されているが確立さ れた手法はない。そこで，筆者らは代表的な以下の 5つの方法について, 支保パターンの剛性を試算し た. なお，それぞれの詳細な算出方法については別 途に取りまとめる ことととし，ここではその概略の み述べる.

\section{a) 北陸自動車道施工技術検討委員会案 ${ }^{10)}$}

北陸自動車道の施工技術検討委員会において提案 された手法である（以下「北陸方式」と呼ぶ）。各 支保部材毎の耐荷能力を吹付けコンクリートは吹付 厚により，ロックボルトは本数により鋼製支保工は, 


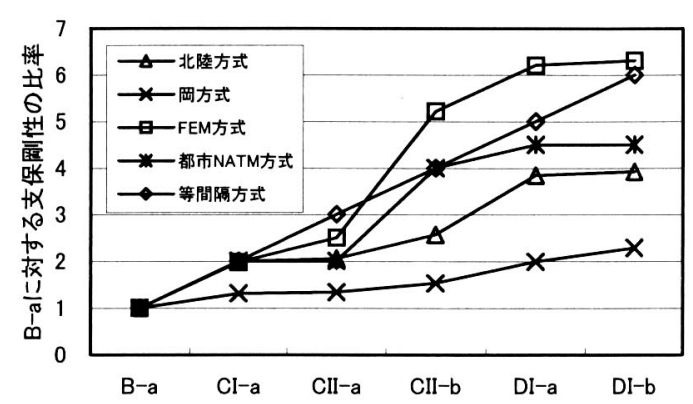

\begin{tabular}{|c|c|c|c|c|c|c|}
\hline & $B-a$ & $\mathrm{Cl}-\mathrm{a}$ & $c 11-a$ & $c \mid 1-b$ & $01-a$ & $01-b$ \\
\hline 北淕方式 & 1.0 & 1. 9 & 2.06 & 2. 57 & 3.84 & 3. 92 \\
\hline 周方式 & 1.0 & 1.31 & 1.34 & 1.53 & 1. 99 & 2.28 \\
\hline FEM方式 & 1.0 & 1.98 & 2.51 & 5.21 & 6.14 & 6.33 \\
\hline 都市NAIM方式 & 1.0 & 2.0 & 2.0 & 4.0 & 4. 5 & 4. 5 \\
\hline 等間膈方式 & 1 & 2 & 3 & 4 & 5 & 6 \\
\hline
\end{tabular}

图ー2 各評価手法による B-a を基準とした剛性比較 9)

そのサイズに対してそれぞれ定め，それらを足し合 わせることにより支保剛性を表現している.

b) 岡の提案による手法 ${ }^{(1)}$

NATM導入期に岡により提案された土压推定式であ り, 支保工の許容応力状態での支保耐力を理論的に 算定する手法である（以下「岡方式」と呼ぶ）。円 形トンネルを仮定し，トンネル掘削により発生する 土压を地山のくさび型押し出し圧力によるものと仮 定し，その押し出し力を支保工で支持する際の荷重 を支保耐力と想定する方法である.ここではその支 保工耐力を支保剛性とした.

\section{c)有限要素法解析から支保工の限界状態を検討した 手法 ${ }^{12)}$}

有限要素法解析による数值シミュレーション用い て, 解析結果の支保部材の応力と限界応力とを比較 することにより各支保パターンにおける限界耐荷能 力の検討を行った結果を用いた方法である（以下 「FEM方式」と呼ぶ）。すなわち, 重力解析により 地山内の応力を再現し, その後掘削応力解析を行う. 覆工は掘削と同時に施工されると考え, 全荷重が支 保工に作用する解析を行う. 解析結果から覆工の曲 げモーメント及び軸力を算出し, 得られた曲げモー メント及び軸力を覆工の断面剛性を表現したM-N曲 線と比較し, 支保工が限界状態に達する際の, 各支 保パターンの初期応力（限界土被り高）の大きさを 算定する.

\section{d) 都市NATM施エデータに基づく提案式 ${ }^{13)}$}

都市部におけるNATM施工事例を基に，標準支保及 び補助工法の支保効果を評価点として提案している 手法である（以下「都市NATM方式」と呼ぶ）. 吹付

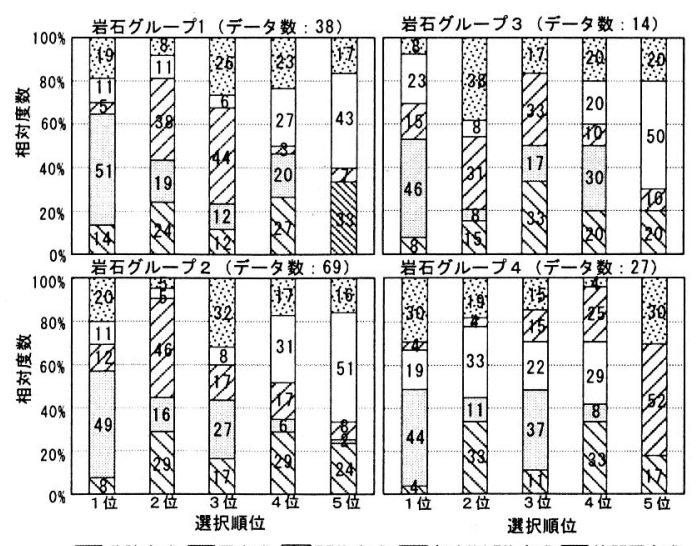

$\square$ 北陸方式 $\square$ 岡方式 凹FEM 方式 Ø都市NAIM 方式 $\square$ 等間隔方式

$$
\text { 図ー3アンケートによる評価結果 }
$$

けコンクリートは吹付厚により，ロックボルトは本 数により点数を与えている. 鋼製支保工の支保効果 に関しては，本手法が都市NATMの補助工法の評価に 主眼をおいているために，決められていない（都市 NATMでは標準的に鋼製支保工を施工するのが一般的 であるため）。補助工法（薬液注入, 鏡ボルト，仮 閉合等）に関してはそれぞれに対応する評価点を定 めた.

\section{e) 等間隔と仮定した案}

支保剛性とは関連がないが， B-aパターンを基準 とし, それぞれの支保パターンの剛性比率が整数倍 になると仮定した案（以下「等間隔方式」と呼ぶ）.

これらの手法をJHで実際に採用されている標準支 保パターン ${ }^{14)} に$ 適用し, B-aパターンとの剛性比と して整理した結果を図ー 2 に示す. 図から明らかな ように, 支保工の限界状態を仮定したFEM方式は, 最も支保剛性の比率が大きい. それに対して地山の 許容応力状態における釣り合いを基礎として支保剛 性を検討している岡方式の変化は最も小さい. 北陸 方式，都市NATM方式は経験的な評価法であり，支保 工の限界状態と許容応力状態の中間的な状態を表す ものと考えられる。

\section{（2）アンケートによる支保剛性の評価}

切羽観察結果と対比させる支保剛性の数值を設定 するにあたり，本論では(1)で述べた各手法が，切 羽観察に直接関与しているトンネル技術者において どのような印象をもたれるかアンケート調査を行い, トンネル技術者の印象と最も適合性の高いと思われ る手法を採用することとした．これは硬質岩から軟 質岩にわたる全ての岩種を対象とした支保剛性算定 に対する理論解が十分得られていない現状を踏まえ， 

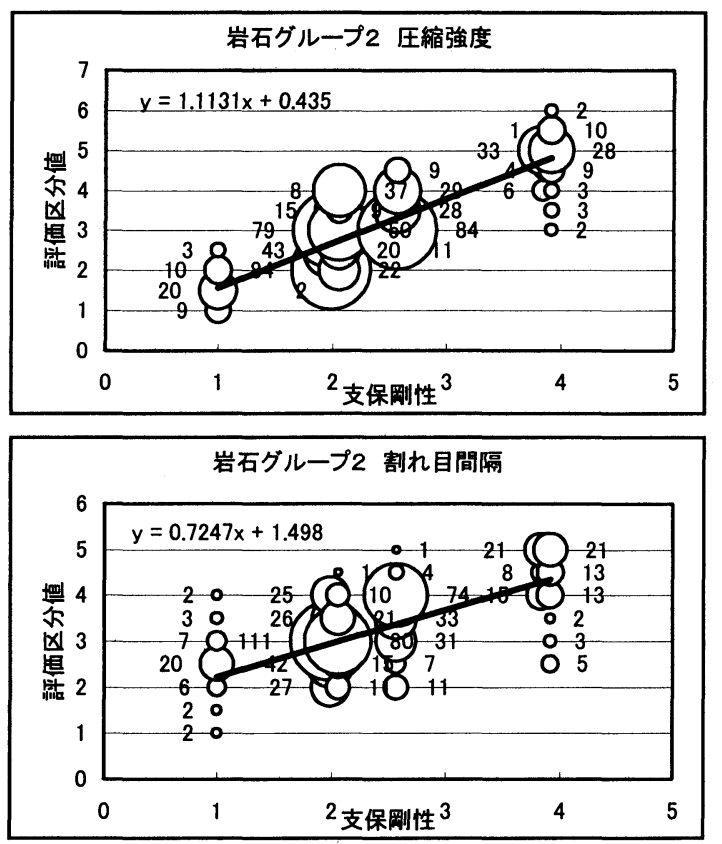
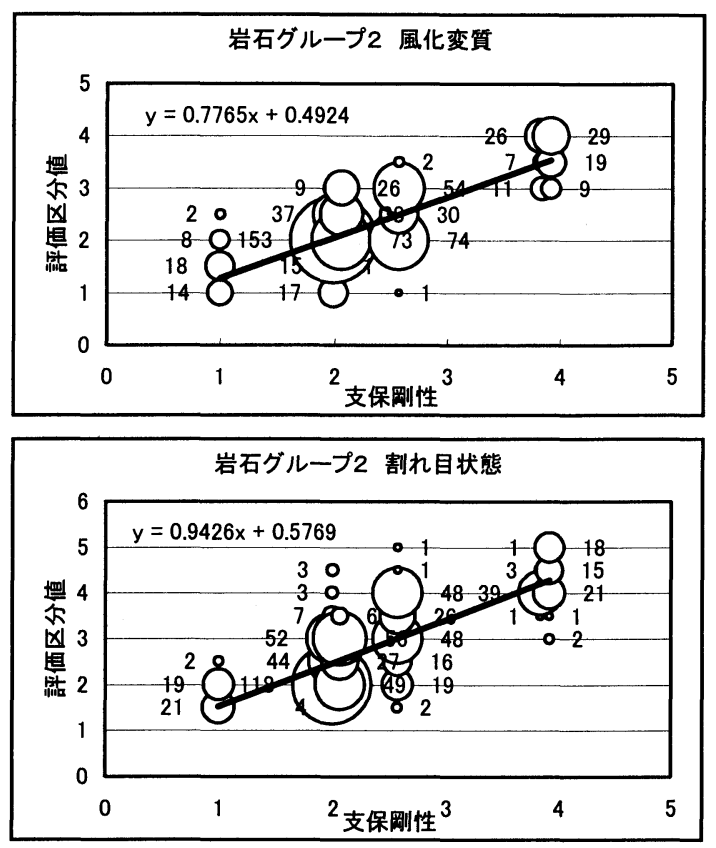

図-4 支保剛性と評価区分値との関係

常に施工性への合理的判断を迫られる技術者の主観 を重視することも1つの規準として許容されると考 えたためである.

アンケートの対象者は, JH, 調査設計コンサル夕 ント, トンネル施工業者に属する技術者総計209名 であった．図ー３に支保剛性比率として適当と思わ れる手法をそれぞれの岩石グループにおいて順位付 けされた結果を示す.

この図より，すべての岩種において，北陸方式 が支保剛性比率として最も適当との印象をもたれて いることがわかる. また逆に，支保剛性比率を等間 隔に割り付けるものは，ほとんどの場合不適当と判 断されている. つまり，トンネル技術者の多くは， 支保剛性比率にはある種の偏りがあるとの印象を持 っていると考えられる.

この結果から, 本論では切羽評価点と対比させる 支保剛性の値として, 北陸方式によるものを採用す ることとした。図ー2 から明らかなように，北陸方 式は，CI-aとCII-a並びにDI-a とDI-bの差がそれぞ れ小さくB-aに対してDI-bの支保剛性が 4 倍程度と 評価される方式である.

\section{(3)各評価区分の配点結果}

a) 分析対象データ

分析に使用したデータは, 新しい切羽観察様式を 用いて切羽観察が実施された平成8年11月から10年 12 月までの2年2か月間に施工されたトンネルを対象
としている. 新しい切羽観察手法は全国規模でJHの トンネル施工現場に導入されたので, 個々のトンネ ルの施工時期が対象期間に合致した現場の切羽観察 データは，ほとんどが収集されている.

当該期間内の新しい切羽観察手法によるデー夕数 は53トンネル，66工区，9,690断面分である. その うち，6種類 (B-a, CI-a, CII-a, CII-b, DI-a, DI-b)の 標準支保パターンで施工されたものは6,101断面で あり (表ー 4 参照), これらのデータを用いて分析を 行うこととする.

\section{b）岩盤強度に関する評価区分の配点検討}

2 章で述べたように，新評価点法は「圧縮強度」， 「風化変質」,「割れ目の間隔」,「割れ目の状態」と いう総合的な岩盤強度に関する 4 項目により最高点 の100点を構成し, その点数に対して,「湧水量」, 「水による劣化」,「不連続面の走向・傾斜」という 場の状態に対する 3 項目の調整点を減じる方式の切 羽評価システムである.ここでは, 総合的な岩盤強 度に関する 4 つの観察項目の支保パターンに与える 奇与度を定量的に評価し，それぞれの観察項目の最 高点を決定する.

奇与度の検討を行うに当り, 表ー 4 で示したデー 夕を以下の条件をもとに選別し, 分析に用いるデ夕を決定した.

(1)土被り条件による選別

坑口部等の低土被り区間の地形条件による支 保選定やそのパターンと本来の支保パターンと 
表ー4 分析対象データの内訳（標準パターン全データ）



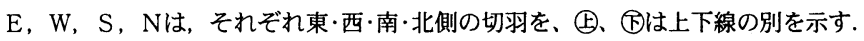
トンネル名の後ろの数字は、観察断面のデータ数を示す. 
の間に設置される遷移パターン等の影響を取 り除くため, 中田らの論文 ${ }^{3)}$ 参考に土被り $40 \mathrm{~m}$ 以上のデータのみ採用することとした。この結 果, 対象とする断面は 4,911 断面となった.

(2)標準偏差による選別

観察項目以外の特殊な条件等で支保が選択さ れている場合の影響を極力取り除くため, 各岩 石グループ, 支保パターンのグループごとに評 価区分值の総和を算出し, 総和が平均值士標準 偏差 $1 \sigma$ の範囲内に収まるデータを抽出し, そ れ以外の断面は除外した.

評価区分值の総和の分布が正規分布と仮定す れば, データの上下約15\%ずつをカットすること になり, 平均的な評価区分値の総和を持つ約 $70 \%$ のデータを用いることとなる.これにより，対 象とするデー夕数は 3,201 断面となった.

(3)湧水・劣化の評価による選別

涌水・劣化の評価が選択された支保パターン に与える影響を取り除くため, 涌水・劣化の評 価区分值が 1 すなわち涌水がほとんどなく, 劣 化もしないと判断されたデータのみを抽出し,

それ以外の断面は除外した. この結果対象とす るデー夕数は1,012断面となる. なお, 涌水・劣 化の影響検討の際には, 再度デー夕を選択する

以上のような条件のもとに最終的に抽出されたデー 夕は49トンネル1,012断面となる. 表一 4 中, 括弧 書きに採用となった個数を合せて示す. その数は, 標準支保パターンの全データの約17\%に相当する. 対象とするデータの内訳を表中に合せて示す．同表 において, 支保パターンでは C I-aパターン (310断 面， $30.6 \%)$ が，また，岩石グループでは中硬質 岩・軟質岩〈塊状〉(673断面, $66.5 \%)$ が最も多く占 めている. 中硬質岩〈層状〉の中・古生層頁岩につい ては, 徳島自動車道, 松山自動車道のトンネルのデ 一夕が主であり, 和泉層群内の砂岩・頁岩互層の地 質データに限定されている.

\section{c）各岩石グループにおける評価配点の検討}

岩石グループ 2 を例として, 支保剛性を横軸に評 価区分の分布を縦軸にとった時の, 観察項目毎の評 価結果の分布を図ー4 に示す．図中の○印の大きさ および数字は, その点の個数の量とその個数を示し ている. 先に述べたように, 図中の横軸は, 北陸方 式の支保剛性で表現しているため, Bのグループ, CI-a とCII-aのグループ, CII-bのグループ, DI-a と DI-bのグループにそれぞれ対応するものの分離が明 らかになる. また, 図中には, 分布から推定した回
岩石グループ1 割れ目間隔

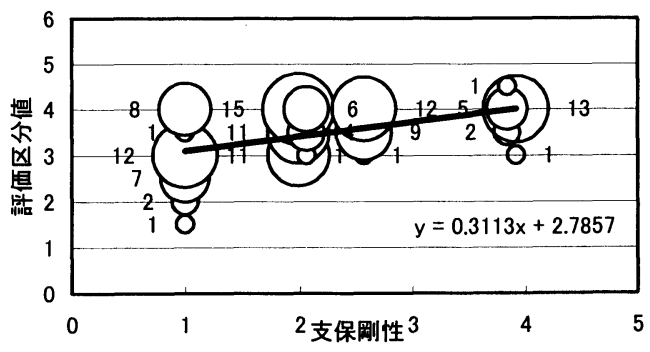

図－5 評価区分值が支保剛性に影響を受けない事例

表一 5 各観察項目における最高点の配点表

\begin{tabular}{|c|c|c|c|c|}
\hline & & 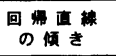 & $\begin{array}{l}\text { 比革 } \\
(\%)\end{array}$ & 高点 \\
\hline \multirow{4}{*}{ 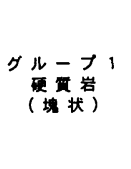 } & 圷部强度 & 0.752 & 39.68 & 40 \\
\hline & 国化变第 & 0.345 & 18.20 & 18 \\
\hline & 割れ目の成届 & 0.311 & 16.41 & 16 \\
\hline & 割れ目の状慗 & 0.487 & 25.71 & 26 \\
\hline \multicolumn{2}{|c|}{ 合 } & 1.895 & 100.00 & 100 \\
\hline \multirow{4}{*}{ 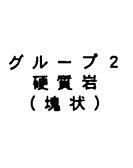 } & 压治強度 & 1.113 & 31.28 & 31 \\
\hline & 化变益 & 0.777 & 21.84 & 22 \\
\hline & 割れ目の间成 & 0.725 & 20.38 & 20 \\
\hline & 割れ目の状管 & 0.943 & 26.50 & 27 \\
\hline \multicolumn{2}{|c|}{ 合 } & 3.558 & 100.00 & 100 \\
\hline \multirow{4}{*}{ 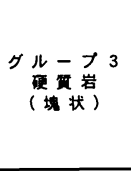 } & 压素缯度 & 1.427 & 32.37 & 32 \\
\hline & 化责页 & 1.149 & 26.07 & 26 \\
\hline & 割れ目の成周 & 0.603 & 13.68 & 14 \\
\hline & 割れ目の状管 & 1.229 & 27.88 & 28 \\
\hline \multicolumn{2}{|c|}{ 合 } & 4.408 & 100.00 & 100 \\
\hline \multirow{4}{*}{ 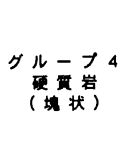 } & 压部強度 & 1.005 & 37.08 & 37 \\
\hline & 化变更 & 0.414 & 15.28 & 15 \\
\hline & 割れ自の成骨 & 0.558 & 20.59 & 21 \\
\hline & 割れ目の状㥈 & 0.733 & 27.05 & 27 \\
\hline \multicolumn{2}{|r|}{ It } & 2.7110 & 100.00 & 100 \\
\hline
\end{tabular}

帰直線を合せて示す．この図から明らかなように, 岩石グループ 2 ではどの観察項目においても, それ ぞれの評価が低下するにつれて，施工される支保は より剛性の高いものが施工されている. すなわち, 支保パターン（軽 $\rightarrow$ 重）を横軸に, 評価程度（良 $\rightarrow$ 不良）を縦軸に整理すると右上がりにデータが分布 している. しかし，図ー5に示す岩石グループ1に おける「割れ目の間隔」の項目のように, 支保剛性 が変化しても評価区分がほぼ一定で大きく変化しな い観察項目もある. 従って, 支保剛性が大きくなる のに対応して評価区分值が大きく変化する場合は, その観察項目の影響が支保剛性に大きく寄与するも の, 逆に, 支保剛性が変化しても, 評価区分の変化 
表-6 各評価項目の配点案

\begin{tabular}{|c|c|c|c|c|c|c|c|}
\hline \multicolumn{2}{|r|}{ 評価区分 } & 1 & 2 & 3 & 4 & 5 & 6 \\
\hline \multirow{4}{*}{$\begin{array}{l}\text { 岩 } \\
\text { 石 } \\
\text { グ } \\
\text { ル } \\
\text { । } \\
\text { プ } \\
1\end{array}$} & 圧縮強度 & 40 & 32 & 24 & 16 & 8 & 0 \\
\hline & 風化变質 & 18 & 12 & 6 & 0 & - & - \\
\hline & 割れ目の間隔 & 16 & 12 & 8 & 4 & 0 & - \\
\hline & 割れ目の状態 & 26 & 19 & 13 & 6 & 0 & - \\
\hline \multirow{4}{*}{$\begin{array}{c}\text { 岩 } \\
\text { 石 } \\
\text { グ } \\
\text { ル } \\
\text { I } \\
\text { プ } \\
2\end{array}$} & 圧縮強度 & 31 & 25 & 19 & 13 & 6 & 0 \\
\hline & 風化变質 & 22 & 15 & 7 & 0 & - & - \\
\hline & 割れ目の間隔 & 20 & 15 & 10 & 5 & 0 & - \\
\hline & 割れ目の状態 & 27 & 20 & 13 & 7 & 0 & - \\
\hline \multirow{4}{*}{$\begin{array}{c}\text { 岩 } \\
\text { 石 } \\
\text { グ } \\
\text { ル } \\
\text { । } \\
\text { プ } \\
3\end{array}$} & 圧縮強度 & 32 & 26 & 19 & 13 & 6 & 0 \\
\hline & 風化变質 & 26 & 17 & 9 & 0 & - & - \\
\hline & 割れ目の間隔 & 14 & 10 & 7 & 3 & 0 & - \\
\hline & 割れ目の状態 & 28 & 21 & 14 & 7 & 0 & - \\
\hline \multirow{4}{*}{$\begin{array}{c}\text { 岩 } \\
\text { 石 } \\
\text { グ } \\
\text { ル } \\
\text { । } \\
\text { プ } \\
4\end{array}$} & 圧縮強度 & 37 & 30 & 22 & 15 & 7 & 0 \\
\hline & 風化変質 & 15 & 10 & 5 & 0 & - & - \\
\hline & 割れ目の間隔 & 21 & 15 & 10 & 5 & 0 & - \\
\hline & 割れ目の状態 & 27 & 20 & 14 & 7 & 0 & - \\
\hline
\end{tabular}

があまりない項目は，その観察項目が支保選択に大 きな影響を及ぼさないものと考えられる.すなわち， 回帰直線の傾きがそれぞれの観察項目に対する寄与 度の大きさを示している.

従って，この回帰直線の傾きに着目し，傾きの値 が大きいほど大きな評価点（最高点）を与えるよう に観察項目の寄与度を考案した. すなわち, 観察項 目における評価区分の和として切羽状態を評価する こととし，各観察項目の傾きの合計が全体として 1 $00 \%$ となるような点数配分を考えた. このように して決定した各観察項目の最高点を表一 5 に示す. また，表一 5 をもとに，各岩石グループの評価区分 をほぼ等間隔で配分した配点表を表一 6 に示す。

表から明らかなように, いずれの岩石グループも 圧縮強度が最も大きな寄与度を持ち, 次に割れ目の 状態が続く，硬岩に適しているとされているRMR2） に比べ, 圧縮強度の寄与度が高く, 割れ目の情報 (割れ目の間隔, 割れ目の状態) が低い傾向を示し た結果となった，硬岩地山では，地山や岩片自身の 強度は高いため, 地山の安定性はブロックの抜け落 ちの判断が重要になると思われる. 従って必要な情 報としては, 割れ目の間隔や割れ目の状態であり,
表 -7 湧水量と劣化の評価区分による分類

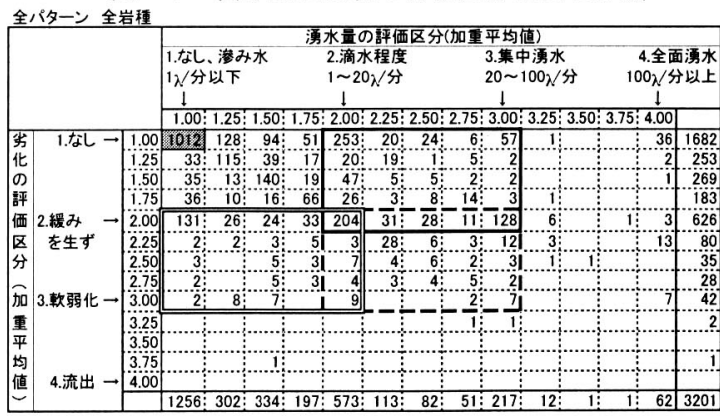

グループA ……浭水量の評価区分が 2 3で、劣化の評価区分が 1 2である924断

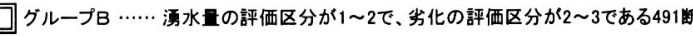
「】グループC ……㴗水量と劣化の評価区分がともに2 3である512断面 甸 グループロ ……涌水量と劣化の評価区分がともに「1」である1.012断面

それらの評価区分の寄与度が大きくなっているもの と思われる，それに対して，日本でよく見られる中 硬質岩〜軟質岩の地山に対しては，地山や岩片の強 度が地山の安定性評価や支保の選定に非常に重要な 要素であり, 岩片の一軸圧縮強度の寄与度が相対的 に大きく評価される結果になったものと推測される.

ここで提案する新しい切羽評価手法は，国内の二 車線道路トンネルの切羽観察結果を評価検討の対象 データとしているため，日本の地山に適した中硬質 岩から軟質岩までを対象とした切羽評価手法になっ たと考えられる.

\section{d）涌水劣化の調整点}

第 2 章 (1)でも述べたように, 新しい切羽観察表 における地山評価の観点は，「総合的な岩盤強度に 対する評価」を行うものと「場の状態に対する評 価」を行うものとに分類している．その観察項目の 中で「湧水量」と「水による劣化」は，後者の評価に当 たり，この評価結果については，岩盤の状況によっ ては支保の選定に直接影響する場合としない場合と があると考えられる，そこで，「湧水量」と「水によ る劣化」の観察項目は，岩盤強度に対する評価に補 正を与える (調整点により減じる方式) 観察項目とし ての位置付けで採用されている.

一方で，「涌水量」と「水による劣化」の評価による 調整点(以下，「湧水調整点」と呼ぶ)の設定に当た り，これらの評価は，岩石グループ並びに評価区分 の違いにより数值化する必要がある.

そこで, 同一岩石グループでありかつ同一支保パ ターンでの切羽評価点（=総合的岩盤強度の評価 点）を，「湧水量」と「水による劣化」の評価区分値が 両者とも「1」と評価された場合 $(=\mathrm{D})$ とそうでな 


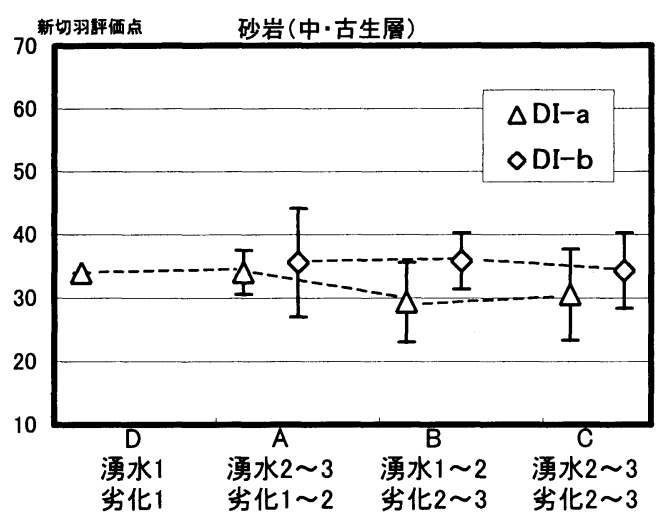

図一 6a(妙口Tn)

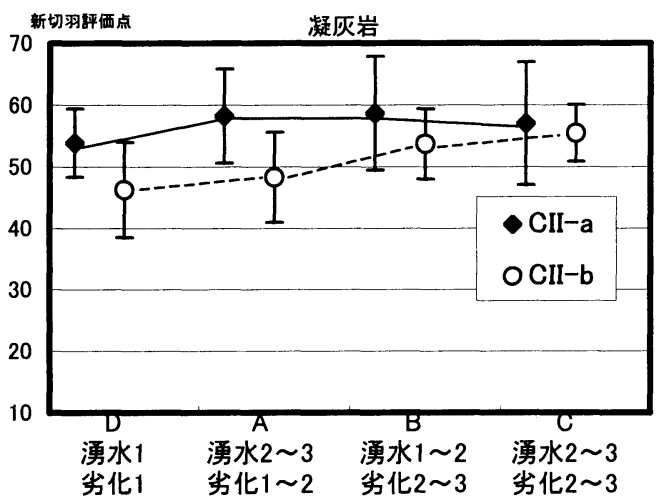

図-6c(袴腰Tn南北工区)

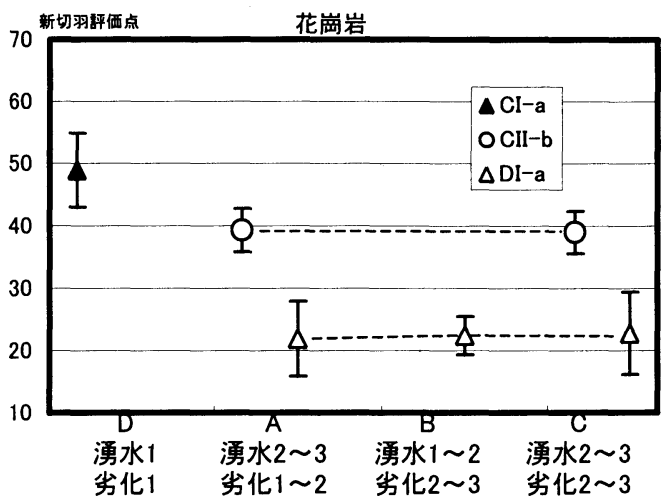

図 $-6 b$ (軽岡Tn北工区)

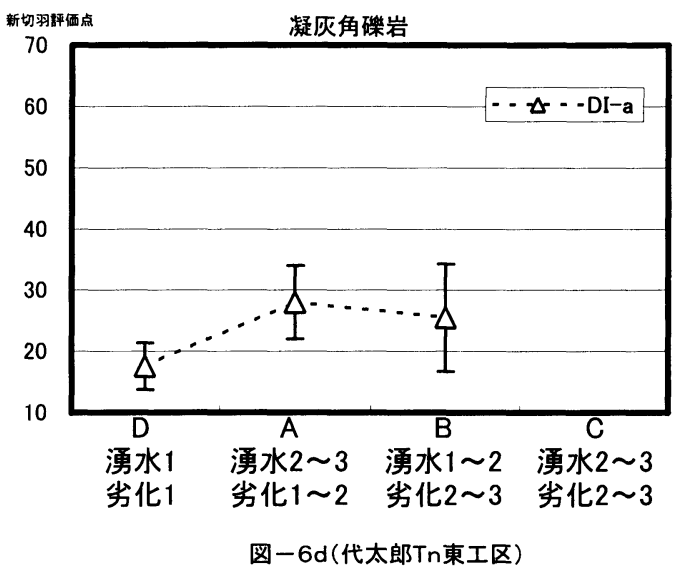

図－6 各トンネルにおける地質毎の湧水・劣化の例

表 -8 湧水 $\cdot$ 劣化の調整点

\begin{tabular}{|c|c|c|c|c|c|}
\hline & \multicolumn{4}{|c|}{$\overline{\text { 区 }}$} \\
\hline & & 1 & 2 & 3 & 4 \\
\hline \multirow{4}{*}{$\begin{array}{l}\text { 区 } \\
\text { 分 }\end{array}$} & 1 & 0 & 0 & -5 & -10 \\
\hline & 2 & 0 & -5 & -7 & -10 \\
\hline & 3 & -5 & -7 & -10 & -15 \\
\hline & 4 & -7 & -10 & -15 & -20 \\
\hline
\end{tabular}

い場合 $(=\mathrm{N})$ に分けて考える. この場合， $\mathrm{N}$ と $\mathrm{D}$ に違いが生じていれば，湧水・劣化により評価が異 なるため、湧水調整点を割り当てる必要がある. 一 般に，ある支保パターンに対応する評価点を固定と した時，同じ支保が選択された切羽であれば，Nは， Dより高い点となっているはずである. すなわち, 湧水調整点は、NからDを減じたものと考えればよ い。逆に, 両者に明確な有意差がない場合は, 涌 水・劣化による奇与度が小さいため, 湧水調整点は 必要ではない.
この考え方に基づき， $\mathrm{N}$ を次の 3 つのグループに 細分し，グループDと比較した.

グループA ‥湧水量の評価がやや悪く $(2.00 〜 3.00)$, 劣化の評価はあまり悪くない(1.00〜 2.00) グループ

グループ B …湧水量の評価はあまり悪くなく $(1.00$ 〜2.00), 劣化の評価がやや悪い (2.00 〜3.00)グループ

グループC …湧水量も劣化も評価がやや悪い (2.00 〜3.00)グループ

ここで, 湧水量と水による劣化の評価区分値が 1.25〜1.75のデータを用いないのは, Dグループと 明確な差を持ったデータと比較したいためである. さらに, 両者の評価区分值が2.0であるデータを重 複して使用したのは, グループ分けの際, 境界上の データを作為的にぼかしたこと並びにそれぞれのグ ループでデー夕数を確保するためである. なお, 湧 水量と劣化の評価区分の值がともに「1」であるグル 一プは, 当初どおりグループDとした，また，それ ぞれのグループの断面数は, 表ー 7 に示すとおりで 


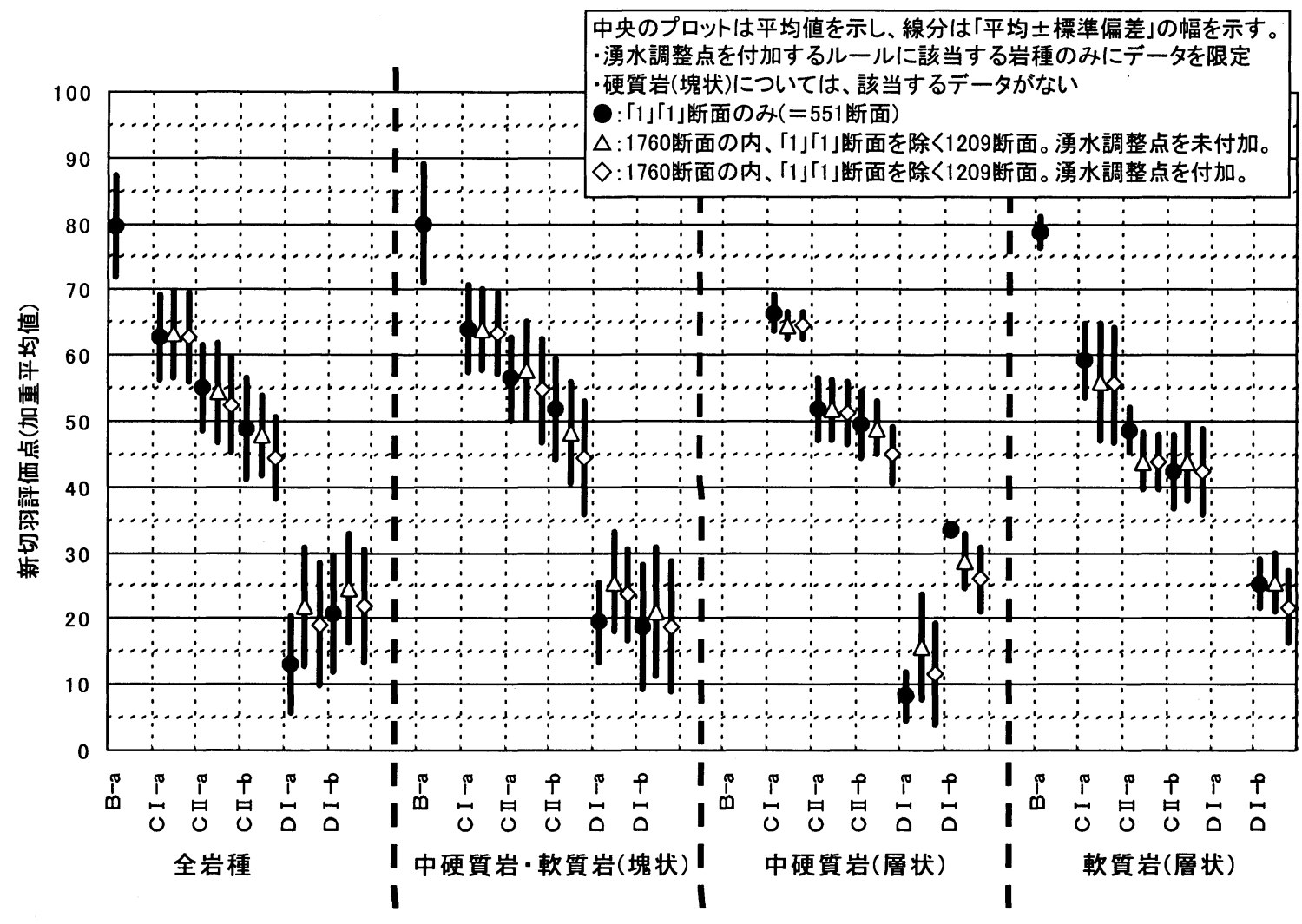

図-7 湧水劣化調整点の検討結果

ある. 表中の断面数の分布に着目してみると, 湧水 量と劣化の評価区分 (加重平均値)がそれぞれ1.00〜 3.00である範囲に 3,122 断面 (97.5\%) が集まってお り，逆にその他の範囲，つまり湧水量や劣化の評価 が特に悪かった断面はごく僅かであったと言える.

特に, 劣化の評価が悪かった (3.0〜4.0)デー夕は 3 断面と少ないことがわかる.

前述のグループ A〜Dを地質每に整理した上で， 個々のトンネルにおいて新切羽評価点を比較した結 果の一例を図ー6に示す. 図では, 各支保パターン における切羽評価点の平均值と標準偏差（士1 $\sigma$ ） の幅を示している. 図一 $6 \mathrm{a}$ の結果から, 砂岩 (中. 古生層)では, 各支保パターンの切羽評価点は, 涌 水量と劣化の評価区分がともに「1」である場合 (グ ループD) と，それらの評価がやや悪くなった場合 （グループA〜C）との比較において，両者とも同程 度の評価点となっている. また，図一 $6 \mathrm{~b}$ に示す花 岡岩の結果では, グループDとグループA〜C とを 直接比較することは出来ないが， C II パターンおよ びD Iパターンにおいてグループ A 〜 C はほぼ一定 值を示すことから，これらの岩石は，湧水調整点を
付加しなくても切羽評価点は同程度であり, 涌水や 劣化の影響を受けないと判断された岩石であると言 える.このような傾向は, 硬質岩(塊状）（岩石グル ープ1），中硬質岩（塊状）（岩石グループ 2 の一 部）に分類される岩石グループにみられる特徴であ り, これらの岩石では, 湧水調整点は適用しないも のとする.

逆に, 図一 $6 \mathrm{c}, \mathrm{d}$ 示す凝灰岩, 凝灰角磁岩の事 例では, 各支保パターンの切羽評価点は, グループ $\mathrm{D}$ と, グループ A 〜 C との比較において, グループ $\mathrm{A} \sim \mathrm{C}$ の方が若干ではあるが高い評価点となる傾向 を示している. つまり，これらの岩石は湧水や劣化 の影響を受けると判断された岩石であると言え, グ ループDとの間に発生する点差（約 $5 〜 10$ 点）を湧 水調整点として設定し, 減じてやれば両者とも同程 度の切羽評価点となる.このような傾向は, 軟質岩 （塊状）（岩石グループ 2 の一部），中硬質岩·軟質 岩（層状）（岩石グループ 3 および 4 ）に分類される 岩石グループに見られる共通の性質であり,これら の岩石については涌水調整点を適用するものとする. 次に,「湧水量」と「水による劣化」の評価区分の違 
いによる影響について, 湧水調整点の配点を具体的 に検討する必要がある.ここでは, 表ー $8{ }^{3)}$ を用い ることとし, それらを前述した涌水調整点の適用す る岩石グループ (軟質岩 (塊状), 中硬質岩・軟質岩 (層状))のデータに代入した. その結果, 表ー 7 に 比較して, 検討に用いるデー夕数は 1760 断面となっ た. そしてそれらのデータの中で, グループD

（551断面）とグループN（1209断面）との比較を した.この結果を図ー 7 に示す．図において，印と 棒の長さは, データの平均とその標準偏差（土1 б）の幅を示す.なお， ○印は，グループDの平均， $\triangle$ 印は, グループNにおいて涌水調整点を未付加の データの平均であり, ○印は, 同グループにおいて 涌水調整点を付加した結果である.

図ー 7 において，の印と $\triangle$ 印を比較すると明らか なように, グループDとグループNの平均值は, 全 岩種を対象とした場合，Cクラスまでの軽い支保の 場合はほぼ等しいが，Dクラスの支保パターンでは 明らかにグループNの評価点が高くなる．これは， 重い支保ほど涌水による影響が大きく，支保パター ン毎に調整点を個別に設定する必要性を示唆してお

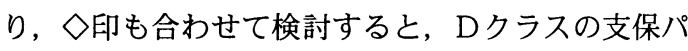
ターンでは, 表ー8より更に大きな調整点が必要と 考えられる. しかし, 岩石グループ毎に分けて検討 すると, 中硬質岩・軟質岩（塊状）の岩種グループ のCクラスの支保パターンでは, 調整点を加えると 平均値の差がさらに拡大する. 従って, 今後の湧水 調整点の取り扱いにあたっては, 今回試行した岩種 による補正のみだけではなく, 支保パターン毎に調 整点を個別に設定するなどの調整点の補正が必要と 考えられる. データの更なる蓄積を図ったうえで, 今後検討していきたい.

\section{4. 新評価点法の適用検討}

表一 6 に示した各観察項目の配点案及び表 -8 に 示す湧水劣化の調整点を用いて 3201 断面の切羽評価 点を計算した. そして, 各支保パターンにおける切 羽評価点の平均およびその標準偏差を検討した，そ の結果を図ー8に示す. 図中ハッチ部分は, この結 果に基づいて定めた理想的な支保選定の目安である. この範囲は, 各支保パターンの平均点を含んで, 理 想的な支保パターンの点数幅を15〜20点程度に設定 している. この配点案と調整点を用いて, 二車線道 路トンネルの切羽観察結果の中からひとつのトンネ ルを選び，縦断面方向に切羽評価点を適用した事例 を図ー9に示す. なお，図で示したトンネルの事例

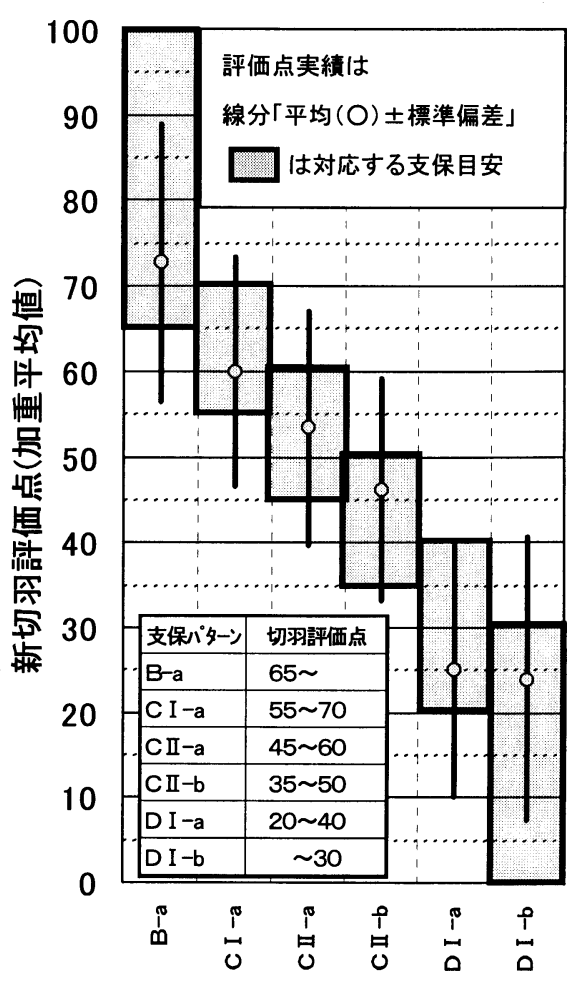

図 - 8 新切羽評価点法と支保選定実績の目安

は，本検討用にトンネルデータを収集した後に施工 されたトンネルであり, 分析用データベースとして は利用していない. 図中に, 施工実績の支保パター ンに基づき，図ー8を参考にしてそれぞれ B-a : 65 点 80点, C I - a : 55点 70点, C II - a : 45点 60 点, C II -b:35点〜 50 点, D III a : 0点の切羽評価点 の範囲を示している. また, 土被りについても合わ せて示す.

図から明らかなように，D III aで示す坑口部の支 保パターンの区間においては, 土被りが大きくなる と同時に切羽評価点も高く, 地山状態が急激に良好 になっていくことが読み取れる. そして，土被りが 20mを超え, 評価点からは C I -aパターンが採用で きる程良好な地山になっていると思われる区間に, 遷移パターンとしてC II-bが採用されている．その ため切羽評価点と実施支保パターンとの間にずれが 生じている. それ以降の切羽評価点は, 理想的な支 保選定の目安の範囲内に収まるだけではなく, 支保 パターンの変更にうまく連動できており, 地山の良 悪の変化をうまく表現している.

坑口部の支保パターンであるD III aは, 地山状態 以外の土被りや偏圧などの要因で支保パターンが決 まることを考えると, 評価点が支保パターンと一致 しないことは自明である. また, 土被りが約 $20 \mathrm{~m}$ 


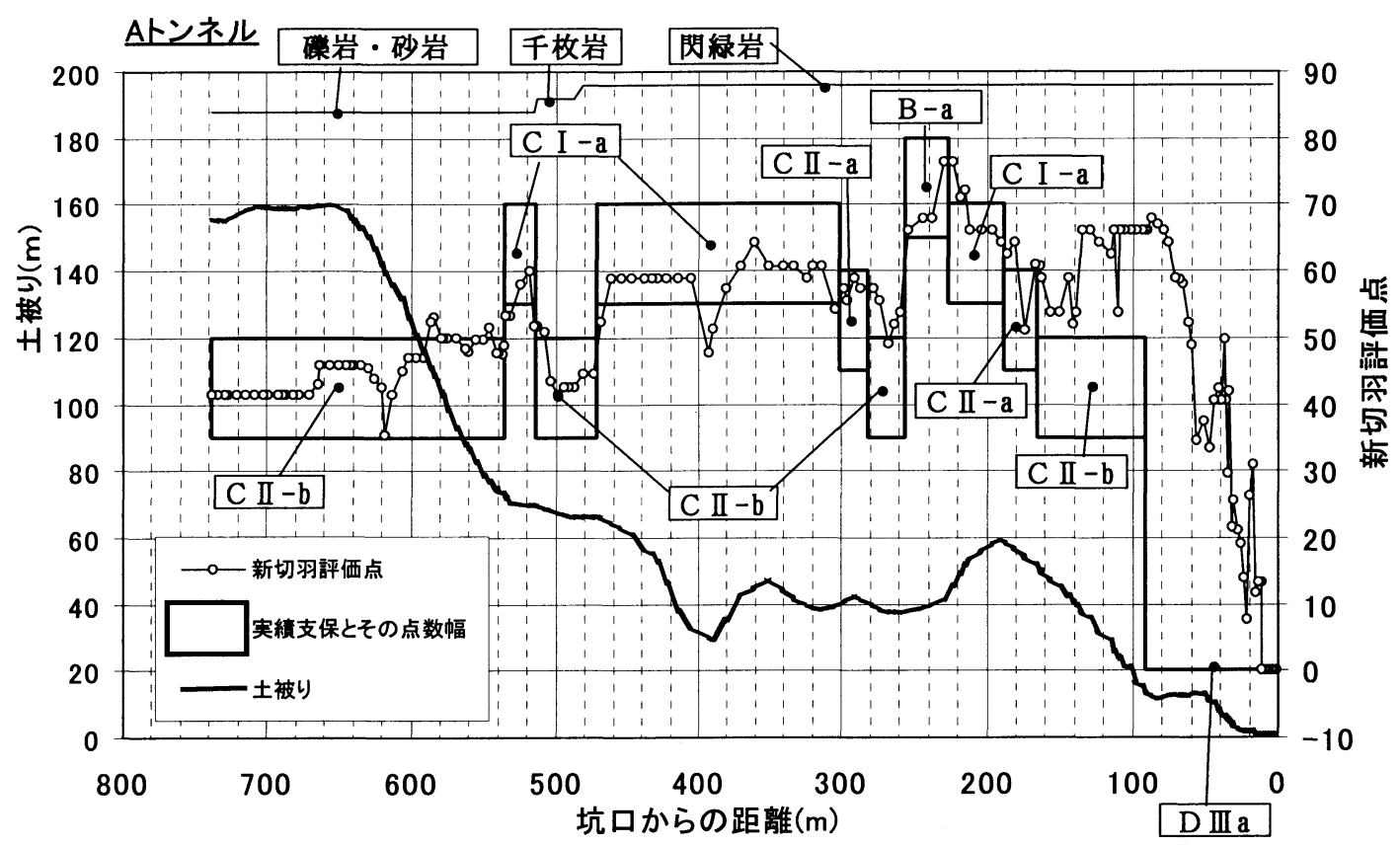

図－9 新切羽評価点法の適用事例

超える段階で C II -bに変更しているが，先にも述べ たようにこの支保パターンが遷移パターンとして採 用されたことを考えると，今回土被り $40 \mathrm{~m}$ 未満の切 羽観察データを不採用とした理由の一つが示されて いる. これらの考察から, 新切羽評価点法は, 全体 として地山評価に極めて有効な方法であるといえる.

\section{5. おわりに}

新評価点法の評価結果と支保パターンとの関連を 整理し，それぞれの評価区分に対してどのように重 み付けをすれば選択した支保パターンと関連がとれ るかについて検討した. その結果, 地山状況をうま く表現できる結果が得られた．しかし，この方法は， 観察者による個人差をいかに小さくし，客観的に切 羽を判断し評価するかが重要である，そのため，JH では，筆者らが中心となって，この方法の説明会お よび現地の切羽観察会を数年に渡って実施している. 今後も,このような取り組みを行いながら, より適 正な地山評価を行うことができるようにデータの蓄 積に努めていきたい。

\section{参考文献}

1) Barton, N., F. Loset, R. Lien and J. Lunde: Application of the Q-system in design decisions concerning dimensions and appropriate support for underground installations, Int Conf. on Sub-surfaceSpace, Rockstore, Stockholm, Subsurface Space, Vol.2, pp.553-561, 1980.

2) Bieniawski, Z. T.: Engineering Rock Mass Classifications, John Wiley \& Sons, 1989.

3）中田 雅博, 三谷 浩二, 八木 弘, 西 琭郎, 西 村 和夫, 中川 浩二 : 切羽観察の分析に基づく新 しい切羽評価システムの提案, 土木学会論文集, No. 623/VI-43, pp. 131-141, 1999.

4) 本間 直樹, 竹田 直樹, 平野 逸雄, 亀村 勝 美 : 膨張性泥岩中に掘削されたトンネルの地山挙動 について, 第18回土質工学研究発表会講演集, pp. $1371-1374,1985$.

5）鈴木 昌次, 古川 浩平, 井上 洋司, 中川 浩二: ファジイ回帰モデルに基づく岩盤分類法の提案，土 木学会論文集, No.418/III-13, pp. 181-190, 1990.

6) 八木 弘, 大津 敏郎, 三谷 浩二, 吉塚 守 : 新標 準支保パターンの導入結果, pp. 26-35, ハイウェイ 技術No. 9, 1997 .

7）今田 徹 : NATM 20 年 我々は何を学んだか, pp. 2635，ハイウェイ技術№. 9, 1997. 
8）鈴木 昌次, 古川 浩平, 井上 洋司, 中川 浩二: アンケートに基づくトンネル施工時の岩盤分類に関 する研究, 土木学会論文集, No.435/VI-15, pp. 5160,1991 .

9）赤木 渉, 西 瑔郎, 進士 正人, 佐野 理, 中川 浩二：アンケートによる技術者の支保剛性に対する 評価について, 第 10 回トンネル工学研究発表 会,pp. 145-148, 2000.

10）財）高速道路技術センター：北陸自動車道上越〜朝 日間総合検討（昭和62年度）第三紀層泥岩地帯にお ける NATMの計測管理検討委員会報告書（総 括）,pp. 115, 1988 .

11）今田 徹: NATMの支保理論, pp. 14-16, NATMの理論 と実際, 土木工学社, 1983.

12）赤木 渉, 三谷 浩二, 吉塚 守：支保耐力を考虑 した新しい切羽評価点法の検討, 土木学会第53回年 次学術講演会, III-B78, 156-157, 1998.

13）櫻井 春輔 編 : 都市トンネルの実際, pp. 132-133, 鹿島出版会.

14）日本道路公団：設計要領第 3 集（1）トンネル本体 工（建設編）, pp. 74-77, 1997.

(2000.8.25 受付)

\title{
A NEW ROCK MASS CLASSIFICATION METHOD AT TUNNEL FACE FOR TUNNEL SUPPORT SYSTEM
}

\author{
Wataru AKAGI, Aya SANO, Masato SHINJI, Takuro NISHI and Koji NAKAGAWA
}

It will be very important for taking measures of tunnel support in either rational or economical way to know either strength or deformability of rock mass at the tunnel face quantitatively. In the paper, the authors propose a new rock mass classification method based on observational results obtained at the tunnel face, which will enable to know appropriate amount of support measure. The study is confirmed by the database consisting of 6,101 sections of tunnels constructed by Japan Highway Public Corporation. The paper additionally discusses the contribution of rock condition against the mechanical rock properties and ground water inflow. An application of the method to the real tunnel construction is also illustrated and the results of application become agreeable reasonably. 